\title{
A prospective study of occupation and prostate cancer risk
}

Citation for published version (APA):

Zeegers, M. P. A., Friesema, I. H. M., Goldbohm, R. A., \& van den Brandt, P. A. (2004). A prospective study of occupation and prostate cancer risk. Journal of Occupational and Environmental Medicine, 46(3), 271-279. https://doi.org/10.1097/01.jom.0000116961.48464.6b

Document status and date:

Published: 01/01/2004

DOI:

10.1097/01.jom.0000116961.48464.6b

Document Version:

Publisher's PDF, also known as Version of record

\section{Please check the document version of this publication:}

- A submitted manuscript is the version of the article upon submission and before peer-review. There can be important differences between the submitted version and the official published version of record.

People interested in the research are advised to contact the author for the final version of the publication, or visit the DOI to the publisher's website.

- The final author version and the galley proof are versions of the publication after peer review.

- The final published version features the final layout of the paper including the volume, issue and page numbers.

Link to publication

\footnotetext{
General rights rights.

- You may freely distribute the URL identifying the publication in the public portal. please follow below link for the End User Agreement:

www.umlib.nl/taverne-license

Take down policy

If you believe that this document breaches copyright please contact us at:

repository@maastrichtuniversity.nl

providing details and we will investigate your claim.
}

Copyright and moral rights for the publications made accessible in the public portal are retained by the authors and/or other copyright owners and it is a condition of accessing publications that users recognise and abide by the legal requirements associated with these

- Users may download and print one copy of any publication from the public portal for the purpose of private study or research.

- You may not further distribute the material or use it for any profit-making activity or commercial gain

If the publication is distributed under the terms of Article $25 \mathrm{fa}$ of the Dutch Copyright Act, indicated by the "Taverne" license above, 


\section{A Prospective Study of Occupation and Prostate Cancer Risk}

\author{
Maurice P. A. Zeegers, PhD \\ Ingrid H. M. Friesema, MSc \\ R. Alexandra Goldbohm, PhD \\ Piet A. van den Brandt, PhD
}

A wide variety of occupations has been associated with prostate cancer in previous retrospective studies. Most attention has been paid to farming, metal working, and the rubber industry. Today, these results cannot be affirmed with confidence, because many associations could be influenced by recall bias, have been inconsistent, or have not been confirmed satisfactory in subsequent studies. This study was conducted to investigate and confirm these important associations in a large prospective cohort study. The authors conducted a prospective cohort study among 58,279 men. In September 1986, the cohort members (55-69 years) completed a self-administered questionnaire on potential cancer risk factors, including job history. Related job codes were clustered in professional groups. These predefined clusters were investigated in 3 time windows: 1) profession ever performed, 2) longest profession ever held, and 3) last profession held at baseline. Follow up for incident prostate cancer was established by linkage to cancer registries until December 1993. A case-cohort approach was used based on 830 cases and 1525 subcohort members. To minimize false-positive results, 99\% confidence intervals (99\% CI) were calculated. Although moderately decreased prostate cancer risks were found for electricians, farmers, firefighters, woodworkers, textile workers, butchers, salesmen, teachers, and clerical workers, none of the relative risks (RR) were found to be statistically significant. For road transporters, metal workers, and managers, no association with prostate cancer risk was found. Although the RR for railway workers, mechanics, welders, chemists, painters, and cooks was moderately increased, these estimates were not statistically significant. For men who reported to have ever worked in the rubber industry, we found a substantially increased prostate cancer risk, but not statistically significant $(R R, 4.18 ; 99 \% C I=$ 0.22-80.45). For policemen, we found a substantial and marginally statistically significant increased prostate cancer risk, especially for those who reported working as a policeman for most of their occupational life $(R R, 3.91 ; 99 \% C I=1.14-13.42)$ or as the last profession held at baseline $(R R, 4.00 ; 99 \% C I=1.19-13.37)$. Most of the previously investigated associations between occupation and prostate cancer risk could not be confirmed with confidence in this prospective study. The lack of statistical significance for rubber workers could be caused by the scarcity of rubber workers in this cohort and subsequent lack of power. The results for policemen were substantial and statistically significant, although a conservative value for significance level was used. (J Occup Environ Med. 2004;46:271-279)

From the Departments of Epidemiology (Dr Zeegers, Dr van den Brandt) and HealthCare Science (Dr Friesema), Maastricht University, Maastricht, The Netherlands; and the Department of Nutritional Epidemiology, TNO Nutrition and Food Research, Zeist, The Netherlands (Dr Goldbohm).

Address correspondence to: Maurice P. A. Zeegers, PhD, Maastricht University, Department of Epidemiology, PO Box 616, 6200 MD Maastricht, The Netherlands; E-mail address: mpa.zeegers@epid.unimaas.nl.

Copyright $(C)$ by American College of Occupational and Environmental Medicine

DOI: 10.1097/01.jom.0000116961.48464.6b he rapidly increasing incidence of prostate cancer in Western countries ${ }^{1}$ calls for attention to the etiology and prevention of this type of cancer. Many risk factors have been proposed to affect the occurrence of prostate cancer. However, despite this effort, the etiology of prostate cancer is still largely unknown, especially when compared with other common cancers.

Potential risk factors that are mentioned are diet, hormones, physical activity, marital status, family history of prostate cancer, race, circumcision, smoking, anthropometry, and occupation. $^{2-15}$ A wide variety of occupations and occupational exposures have been associated with prostate cancer in predominantly retrospective studies. Reviews on this topic are scarce and nearly always focused on one job category. ${ }^{16-22}$ Most attention has been paid to farming, metal working, and the rubber industry. ${ }^{23}$ Exposures that are linked to these occupations are herbicides and pesticides, cadmium, polycyclic aromatic hydrocarbons, and engine emissions. $^{24-26}$

However, there has been no profession for which an association has been decisively established. Many occupational associations could have been influenced by recall bias. Recall bias is especially hazardous in retrospective case-control studies in which cases and controls might have differential recollection of potential risk factors of cancer. Also, many occupations have been investigated insufficiently, because their frequency in the general population is too low to calculate disease risk es- 
timates. The aim of this article is to investigate the association between occupation and prostate cancer risk within a prospective cohort study, which prevents recall bias. The cohort is based on 58,279 populationsampled male participants leaving a wide range of professions to be examined with sufficient frequency.

\section{Methods}

\section{Study Population}

The study design, including data collection strategies, has been described in detail previously. ${ }^{27}$ In short, the cohort includes 58,279 men aged 55 to 69 years at baseline. The study population originated from 204 municipal population registries throughout The Netherlands. The case-cohort approach was used for data processing and analysis. ${ }^{28}$ Cases were enumerated from the entire cohort, whereas the accumulated person-years in the cohort were estimated from a subcohort sample. Following this approach, a subcohort of 1688 men was randomly sampled from the cohort after baseline exposure measurement. The subcohort has been followed up for vital status information. No subcohort members were lost to follow up.

\section{Follow Up}

Follow up for incident cancer was established by record linkage of the full cohort to cancer registries and the Dutch national database of pathology reports. ${ }^{29}$ The completeness of cancer follow up was estimated to be over $95 \% .^{30}$ The presented analysis is restricted to cancer incidence in 7.3 years of follow up, from September 1986 to December 1993. After excluding prevalent cases with cancer other than skin cancer, a total of 1630 male subcohort members and 903 men with microscopically confirmed incident carcinomas of the prostate were available for this study. Inclusion of prevalent cases could have yield to biased results, because patients with cancer could have adjusted their lifestyle after diagnosis.

\section{Exposure Assessment}

At baseline, the cohort members completed a mailed, self-administered questionnaire on potential confounders and other risk factors for cancer. In this questionnaire, occupational history was addressed by questions on each occupation in paid employment they had ever held along with the years they had occupied those jobs with a maximum of 5 occupations. The job titles were coded using the Dutch Occupation Classification System of the "Centraal Bureau voor de Statistiek."31 All job codes were mutually exclusive. Related job codes were clustered in professional groups: farmer (eg, poultry farmer, lowland farmer), railway worker (eg, train guard, train driver), road transportation (eg, cap driver, truckdriver), firefighter, policeman (eg, police officer, police inspector, detective), mechanic (eg, maintenance mechanic, repairman), welder (eg, iron welder, lead solder), metalworker (eg, galvanizer, fitter), woodworker (eg, carpenter, cabinet maker), textile worker (eg, upholsterer, embroiderer), rubber worker (eg, tire vulcanize, rubber laminator), chemist (eg, physicist, laboratory attendant), painter (eg, house painter, car sprayer), electrician (eg, car electrician, electrical installation engineer), butcher (eg, butcher, poulterer), cook (eg, cook, kitchen maid), salesman (eg, shop assistant, newspaperman), teacher (eg, professor, infant schoolteacher), clerical worker (eg, counter clerk, administrator), and manager (eg, plant manager, director). A complete list of Dutch job titles organized by professional group is available on request. To minimize false-positive results, only these predefined clusters were tested in 3 time windows: 1) profession ever performed, 2) longest profession ever held, and 3) last profession held at baseline.

\section{Statistical Analyses}

Both age-adjusted and multivariable adjusted incidence rate ratios
(RR) relating the 3 time windows for each profession to prostate cancer risk were estimated using exponentially distributed failure time regression models ${ }^{32}$ with the Stata statistical software package. ${ }^{33}$ In all analyses, the robust standard error estimation was used to account for additional variance introduced by sampling from the cohort. ${ }^{34,35} \mathrm{Be}$ cause many associations have been tested, we have minimized the probability of false-positive results by calculation $99 \%$ confidence intervals (99\% CI) rather than using a Bonferroni correction, because it is an overly severe correction $^{36}$ that would have caused excessive loss of sensitivity (statistical power). The following variables were included as covariates in multivariable analyses based on their independent effects in the Netherlands Cohort Study ${ }^{2-5}$ and other earlier studies on prostate cancer risk factors ${ }^{7-15}$ : age (years); firstdegree family history of prostate cancer (yes/no); consumption of vegetables, fruit, dairy products, meat, and alcohol (g/day); years of cigarette smoking, number of cigarettes smoked per day; level of education (no education of primary school, lower occupational training, medium occupational training, high education level [ie, university]); and level of physical activity (no, low, medium, high). Because the multivariable analyses included dietary covariates, men with incomplete or inconsistent dietary data were excluded, leaving 830 cases with prostate cancer and 1525 subcohort members available for all analyses. Sensitivity analyses showed that this exclusion did not change the results substantially. Because of sparse data, it was not possible to evaluate the occupational associations separately for advanced and localized prostate cancer cases.

\section{Results}

Most prostate cancer cases $(\mathrm{n}=$ $765,92 \%)$ and subcohort members $(\mathrm{n}=1390,91 \%)$ provided information on their job history. Table 1 describes the covariates used in mul- 
TABLE 1

Description of Potential Confounding Factors For Prostate Cancer Cases and Subcohort Members, Netherlands Cohort Study (1986-1993)

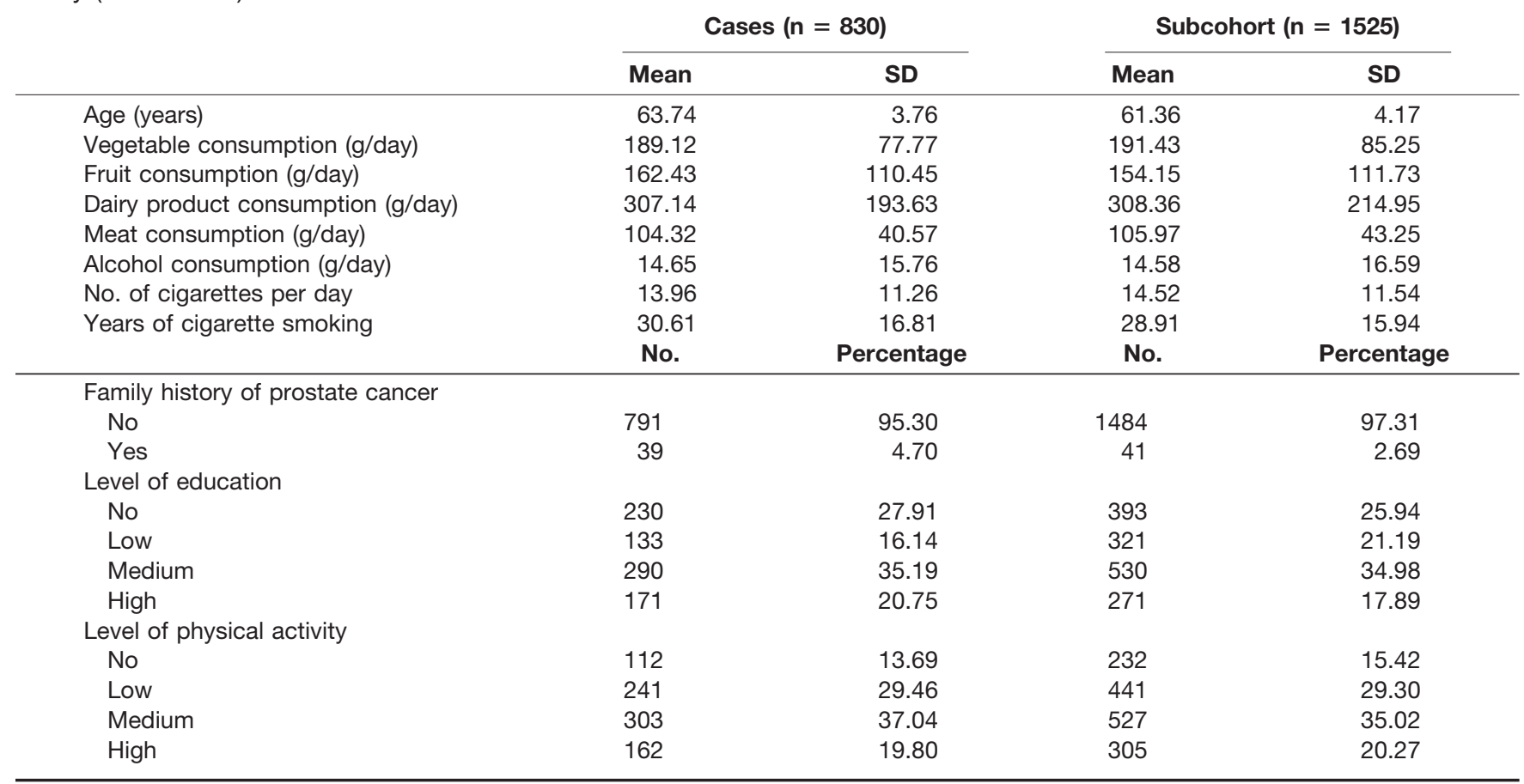

SD, standard deviation.

tivariable regression analyses for prostate cancer cases compared with subcohort members separately. On average, the cases were 63.74 $( \pm 3.76)$ years old at baseline and the subcohort members were 61.36 ( \pm 4.17$)$ years old. The distribution of other potential confounders appeared to be comparable between cases and subcohort members, except for first-degree family history of prostate cancer, which was more frequently reported by the cases $(4.70 \%)$ than by the subcohort members $(2.69 \%)$ (Table 1).

For clarity, we have categorized the estimated associations into $5 \mathrm{lev}$ els: substantial decreased risk $(\mathrm{RR}<$ $0.4)$, moderately decreased risk $(0.4 \leq \mathrm{RR}<0.8)$, no association $(0.8 \leq \mathrm{RR}<1.2)$, moderately increased risk $(1.2 \leq \mathrm{RR}<2.5)$, and substantially increased risk $(\mathrm{RR} \geq$ 2.5).

\section{Substantially Decreased Risk}

Incidence rate ratio estimates for professions ever performed, longest professions ever held, and last professions held at baseline are presented in Table 2. Except for electricians, none of the investigated occupations appeared to be associated with a substantially decreased prostate cancer risk compared with the risk in the general population after multivariable adjustment. Although the effect estimate for those having worked as a electrician at baseline showed a substantial multivariable adjusted decreased prostate cancer risk $\left(\mathrm{RR}_{\text {baseline }}=0.18\right)$, this is based on few electricians and subsequently has low power. However, also in other time windows, decreased risks for electricians were found.

\section{Moderately Decreased Risk}

We have found moderately decreased prostate cancer risks in at least one time window for: farmers $\left(\mathrm{RR}_{\text {longest }}=0.70, \mathrm{RR}_{\text {baseline }}=\right.$ 0.75$,$) , firefighters \left(\mathrm{RR}_{\text {ever }}=0.59\right.$, $\left.\mathrm{RR}_{\text {longest }}=0.69\right)$, woodworkers $\left(\mathrm{RR}_{\text {longest }}=0.65, \mathrm{RR}_{\text {baseline }}=0.71\right)$, textile workers $\left(\mathrm{RR}_{\text {longest }}=0.58\right.$, $\left.\mathrm{RR}_{\text {baseline }}=0.40\right)$, electricians $\left(\mathrm{RR}_{\text {ever }}=0.61, \mathrm{RR}_{\text {longest }}=0.48\right)$, butchers $\left(\mathrm{RR}_{\text {longest }}=0.71, \mathrm{RR}_{\text {baseline }}\right.$ $=0.50)$, salesmen $\left(\mathrm{RR}_{\text {longest }}=\right.$ 0.67, $\left.\mathrm{RR}_{\text {baseline }}=0.69\right)$, teachers $\left(\mathrm{RR}_{\text {longest }}=0.69, \mathrm{RR}_{\text {baseline }}=0.76\right)$, and clerical workers $\left(\mathrm{RR}_{\text {ever }}=0.74\right.$, $\mathrm{RR}_{\text {longest }}=0.64, \mathrm{RR}_{\text {baseline }}=0.67$ ). However, none of these estimates were found to be statistically significant.

\section{No Association}

We could not identify an association with prostate cancer risk in any time window for road transporters $\left(\mathrm{RR}_{\text {ever }}=1.10, \mathrm{RR}_{\text {longest }}=0.96\right.$, $\left.\mathrm{RR}_{\text {baseline }}=1.01\right)$, metal workers $\left(\mathrm{RR}_{\text {ever }}=0.92, \mathrm{RR}_{\text {longest }}=1.00\right.$, $\left.\mathrm{RR}_{\text {baseline }}=1.05\right)$, or managers $\left(\mathrm{RR}_{\text {ever }}=1.14, \mathrm{RR}_{\text {longest }}=0.98\right.$, $\mathrm{RR}_{\text {baseline }}=1.13$ ).

\section{Moderately Increased Risk}

In at least one time window, moderately increased prostate cancer risks were found for railway workers 


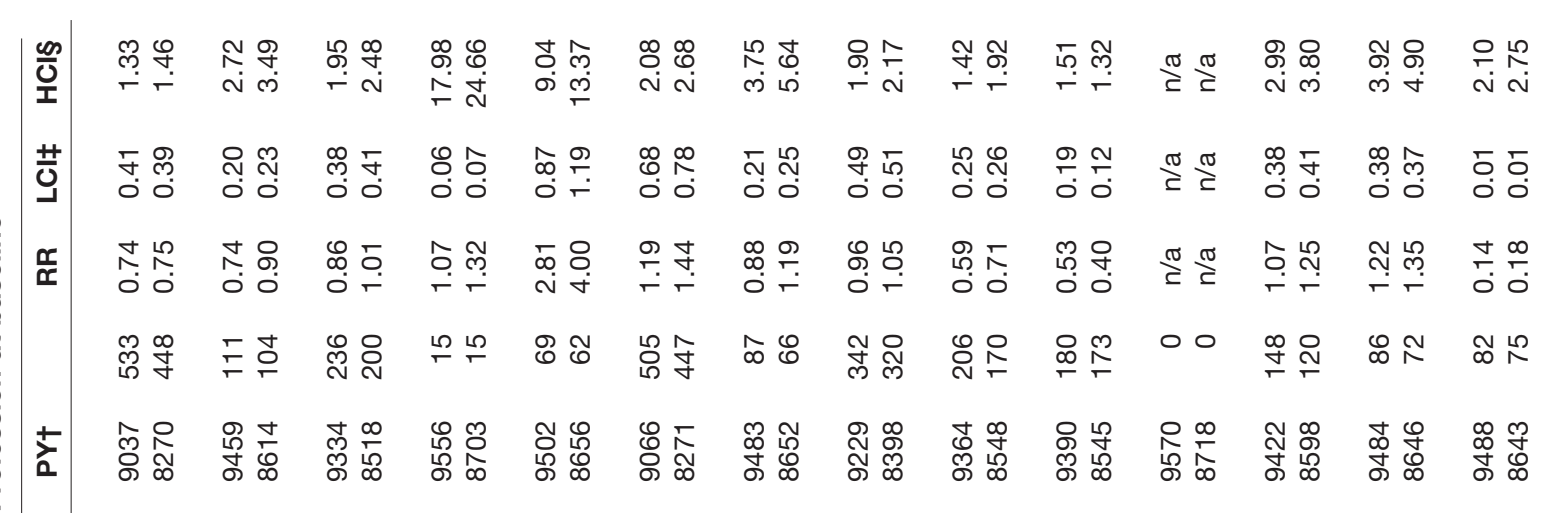
กิN 00 도 N

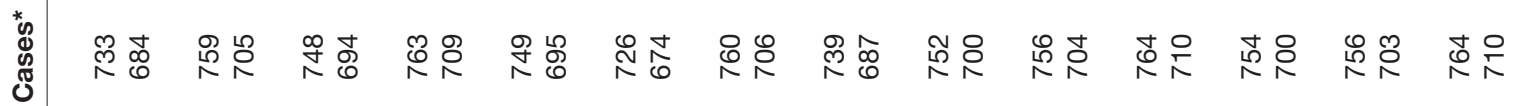

禹

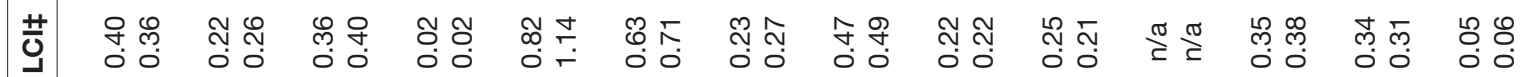

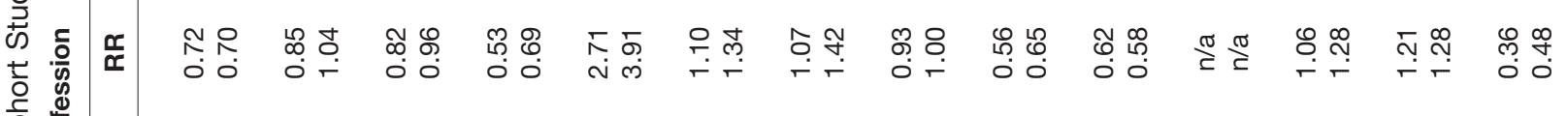
容产 尊导

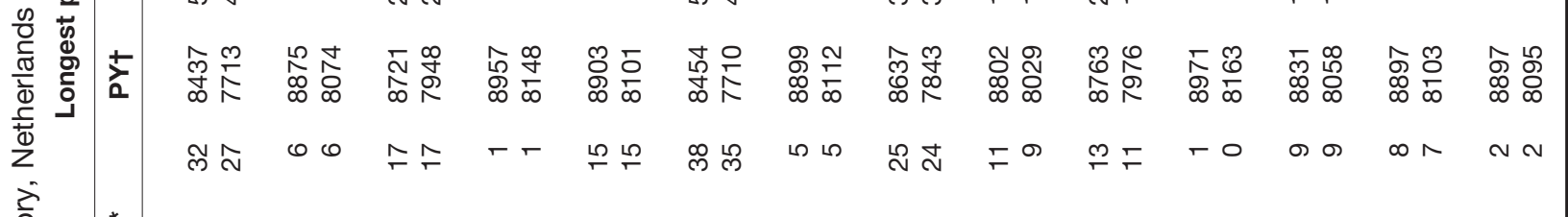

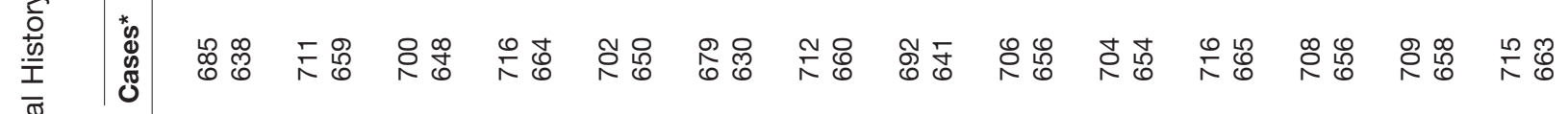

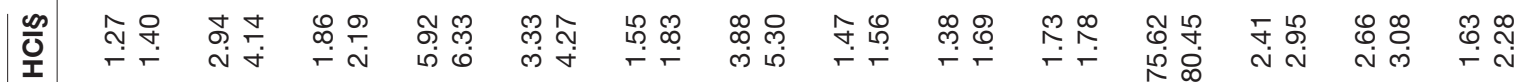

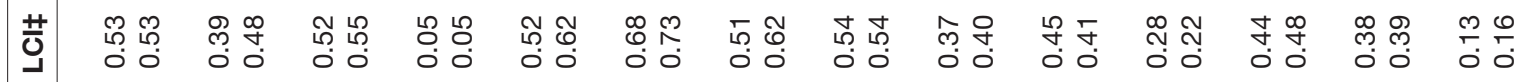
요

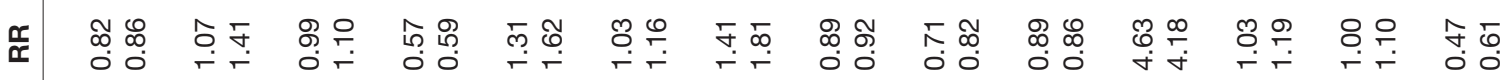

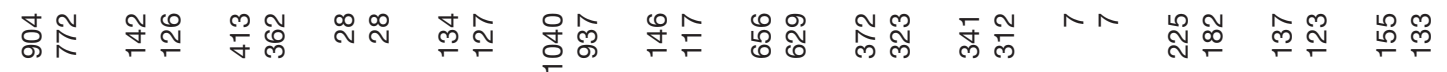

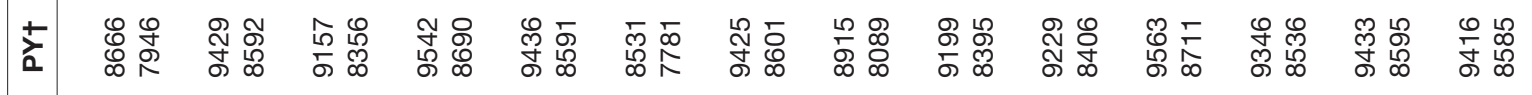

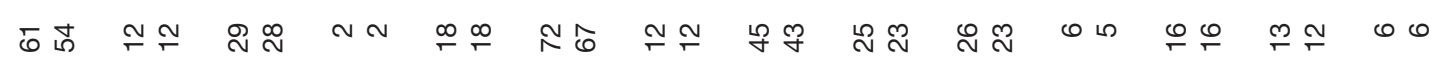

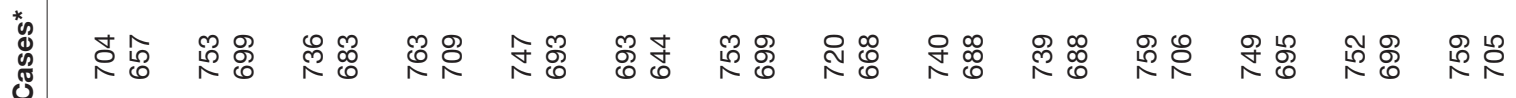




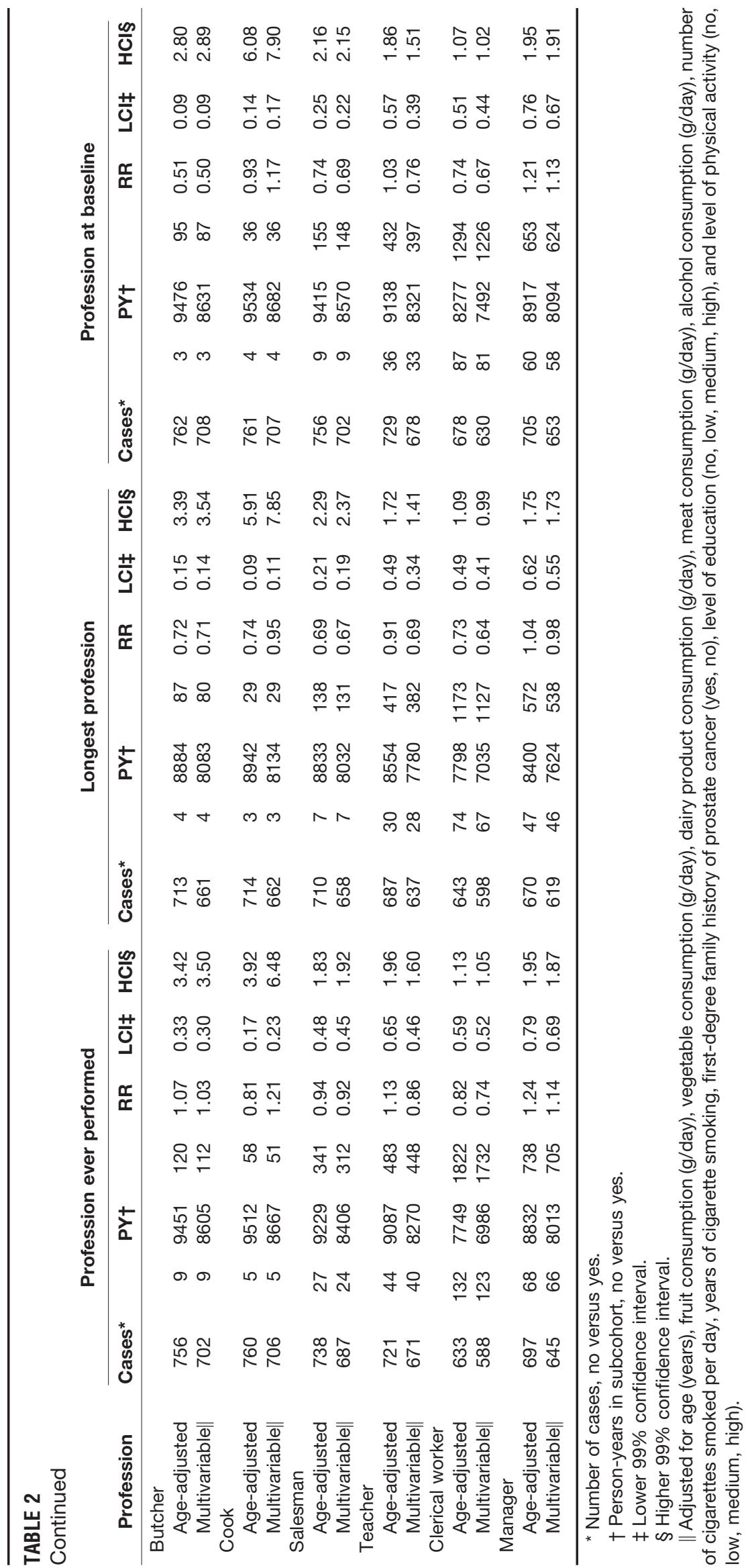


$\left(\mathrm{RR}_{\text {ever }}=1.41\right)$, policemen $\left(\mathrm{RR}_{\text {ever }}=\right.$ $1.62)$, mechanics $\left(R_{\text {longest }}=1.34\right.$, $\left.\mathrm{RR}_{\text {baseline }}=1.44\right)$, welders $\left(\mathrm{RR}_{\text {ever }}=\right.$ $\left.1.81, \mathrm{RR}_{\text {longest }}=1.42\right)$ and chemists $\left(\mathrm{RR}_{\text {longest }}=1.28, \mathrm{RR}_{\text {baseline }}=1.25\right)$, painters $\left(\mathrm{RR}_{\text {longest }}=1.28, \mathrm{RR}_{\text {baseline }}\right.$ $=1.35)$, and cooks $\left(\mathrm{RR}_{\text {ever }}=1.21\right)$. However, none of these estimates were found to be statistically significant.

\section{Substantially Increased Risk}

For men who reported to have ever worked in the rubber industry, we found a substantially increased prostate cancer risk, but not statistically significant $\left(\mathrm{RR}_{\mathrm{ever}}=4.18\right)$. For policemen, we found a substantially increased prostate cancer risk for those for who reported working as a policeman for most of their occupational life $\left(\mathrm{RR}_{\text {longest }}=3.91\right)$ or as the last profession held at baseline $\left(\mathrm{RR}_{\text {baseline }}=4.00\right)$. These estimates appeared to be statistically significant. After repeating all analyses with $95 \%$ confidence intervals, these RRs also appeared to be the only effect estimates that reached statistical significance (95\% $\mathrm{CI}_{\text {longest }}: 1.53$ 9.99; 95\% $\mathrm{CI}_{\text {baseline: }}$ 1.59-10.02). Additional analyses according to duration of longest held profession showed that the risk of prostate cancer increases $67 \%(95 \% \mathrm{CI}=1.10$ 2.54) for each 10 years of occupational duty as a policeman. Almost all policemen included in this study have been working as a general police officer (18 cases and 53 subcohort members). Only 1 prostate cancer case and 3 subcohort members have worked as a police detective. Also, men who reported to have ever worked as a policeman were found to have increased prostate cancer risk (see previous paragraph).

\section{Discussion}

These data showed that the prostate cancer incidence in most occupational groups was comparable with the incidence in the general population. The few number of associations detected in the study could be explained by potential inclusion of latent or undiagnosed cases among participants categorized as noncases, which could have led to an attenuation of risk estimates. Nevertheless, policemen appeared to have substantial higher incidence rates. Also, the incidence of prostate cancer is found to be substantially higher among workers in the rubber industry and substantially lower among electricians. However, the results of these latter professions are uncertain as a result of low numbers.

\section{Methodology}

Occupational history has been assessed by using self-administered questionnaires. Most men will remember their previous occupations because most occupations will be practiced at least several months. ${ }^{37}$ The exact dates, however, might have caused difficulties because this refers to one specific moment in time. This could have biased the results for the "longest profession ever held" but not for the "profession ever performed" or the "last profession held at baseline." The results for these different time windows, however, have been comparable for most occupational groups.

This study was performed within the general population of The Netherlands. An advantage of using such a broad and large group of men is the wide range of professions that can be examined with sufficient frequency. However, this also implies small groups of relative rare professions could not be related with prostate cancer with sufficient confidence. The large number of prostate cancer cases in this study was another important advantage.

We were not able to explain our results on the basis of confounding, because our results were essentially unchanged after incorporating into the analyses many known or suspected risk factors for prostate cancer, including age; family history of prostate cancer; consumption of vegetables, fruit, dairy products, meat, and alcohol; cigarette smoking; and level of education. It should be considered that confounding bias can never be completely eliminated, because many determinants of prostate cancer are still unknown. Also, all potential confounders were measured at baseline. This information might not capture the changes that could have occurred before or after the baseline period. We have not adjusted for ethnicity, because all participants were white.

\section{Previous Studies}

All the occupational groups that have been investigated in this study have been studied previously in more or less detail. Therefore, our results will be compared with other studies. Reviews on this topic are rare and are all about farmers, ${ }^{16-19,21}$ mechanics and metal workers, ${ }^{22}$ or rubber workers ${ }^{20}$

Both narrative and systematic reviews have questioned increased prostate cancer risk for farmers. ${ }^{16-19,21} \mathrm{Al}$ though previously reported increased risks were statistically significant, they appeared to be small and therefore clinically irrelevant. Within our study also, no considerable association or even a moderately decreased risk for prostate cancer was found.

The results from earlier studies among railway workers have not been consistent. Some found slightly to substantially increased prostate cancer risk among railway workers, ${ }^{38,39}$ whereas other studies found no association..$^{40,41}$ In our study, a moderately, nonsignificant increased risk was found for profession at baseline, but no association in other time windows. No association was found for those having worked as a road transporter. This is consistent with some studies, ${ }^{24,26,42,43}$ although others reported decreased risks. ${ }^{25,26,39}$

We investigated possible prostate cancer risk among those serving in firefighter and police forces. However, the number of firefighters with prostate cancer in our study population was too small to assess a reliable rate ratio. The number of policemen was sufficiently large; the corresponding rate ratio indicated a significant increased prostate risk, although a conservative alpha-level 
was used. The rate ratio for those reporting to have worked as a policeman for most of their occupational life (RR, 3.91; 99\% CI, 1.14-13.42) or as the latest profession at baseline (RR, 4.00; 99\% CI, 1.19-13.37) is substantially higher than for those reporting to have ever worked as a policeman regardless of duration (RR, 1.62; 99\% CI, 0.62-4.27). Because almost all policemen have been working as a general police officer, no more detailed analysis on job function was possible. Earlier studies also found increased risk ratios, ${ }^{24-26}$ although Finkelstein ${ }^{44}$ found no association and Forastiere et al. ${ }^{45}$ reported a slightly decreased risk. It is, however, unclear what carcinogen could be responsible for this increased risk. One possibility could be the radar devices that emit nonionizing, microwave radiation, but no research has been done in this field yet. ${ }^{44}$

There does not seem to be an association between prostate cancer and metal workers and a moderate, nonsignificant increased risk for mechanics. One review on this topic concluded that mechanics and metal workers possibly run a slightly elevated risk. ${ }^{22} \mathrm{~A}$ problem with mechanics, and even more for metal workers, is the wide range of occupations within these definitions and consequently the exposure to many different possible risk factors as metals, metallic compounds, chemicals, and oils. Job titles alone are poor indicators of specific chemical exposures. Although for welding fumes, no association or even a decreased risk for prostate cancer have been reported, 22,25,46,47 we found a moderate, nonsignificant risk for men who worked as a welder. Two other studies $^{38,48}$ also reported an increased risk, although others could not confirm these findings. ${ }^{42,43}$

For woodworkers, a nonsignificant moderately decreased risk was found. Andersen et al. $^{43}$ also reported a small significant decreased risk, whereas others found no association ${ }^{24,25,38,41,42,49}$ or an increased risk. ${ }^{25,50,51}$ For textile workers, the results were not consistent with other studies. For longest profession, a relative risk of $0.58(99 \% \mathrm{CI}=0.21-1.58)$ was found, whereas other studies have reported no association ${ }^{38,43,50}$ or increased risk ratios. ${ }^{38,46,50}$

Although the relative risk for rubber workers showed a substantially increased prostate risk (RR, 4.18; $99 \% \mathrm{CI}=0.22-80.45$ ), this was based on very few cases and subcohort members. The results are therefore not reliable. As a result of this scarcity of data, we were not able to estimate rate ratios for rubber workers in other time windows. Other articles on this topic are inconsistent. $^{20}$

Chemists seems to have a moderately increased risk of developing prostate cancer, as also reported by Krstev et al., ${ }^{26}$ Aronson et al., ${ }^{38}$ and Hoar and Blair. ${ }^{50}$ However, other studies found rate ratios around $1.0^{24,38,41}$ or a decreased risk. ${ }^{25,43}$ The differences in findings could be the result of the great diversity of chemicals of which these professionals are exposed to.

For painters also a moderately increased prostate cancer risk was found. Some earlier studies ${ }^{43,52,53}$ did not find an association, although one study ${ }^{42}$ also found a moderately increased risk $(\mathrm{RR}, 1.3 ; 95 \% \mathrm{CI}=$ 0.5-3.5). Major potential carcinogenic exposures of a painter, paint components and polycyclic aromatic hydrocarbons, could be a risk factor for prostate cancer. ${ }^{25,42,54}$

Men who have ever worked as an electrician seem to have a moderately, nonsignificant decreased risk of developing prostate cancer. The relative risk for men who have worked as an electrician at baseline showed a substantial decreased risk (RR, 0.18; 99\% CI $=0.01-2.75)$. However, the number of electricians in our study was very small, eg, only one case with prostate cancer reported to have worked as an electrician at baseline. Therefore, these findings are not reliable and can only be interpreted as suggestive findings. Previous studies have found no association. $^{24,25,43,53}$

Moderately decreased risks were found for butchers and moderately increased risks were found for cooks. Studies about these 2 professions are not consistent. Van der Gulden et al. ${ }^{25}$ reported an increased prostate cancer risk for butchers, but 3 other studies ${ }^{41,55,56}$ did not find a substantially altered risk. For cooks, no risk $^{38}$ or a decreased risk ${ }^{26,56,57}$ was reported.

Salesmen seem to have a moderately, nonsignificant decreased risk of developing prostate cancer. Other articles on this topic $24,25,39,41-43,54,58,59$ are equivocal. The point estimates vary between $0.68^{58}$ and $1.78,{ }^{59}$ only one ${ }^{43}$ being statistically significant.

For teachers, a moderately decreased association was found, which was not reported by other studies. Four earlier studies did not find an association, ${ }^{24,25,41,43}$ whereas 2 other studies ${ }^{26,57}$ found significant increased risk with point estimates between 1.3 and 3.1.

Clerical workers appear to have a moderately, but nonsignificant, decreased risk of developing prostate cancer. Only one study ${ }^{25}$ has reported similar results, also nonsignificant. Most studies $^{38,39,42,54,59}$ did not find an association. Some studies have reported small increased rate ratios. ${ }^{24-26,39,43}$

Finally, the risk ratios estimated within our study for managers correspond with other publications, ${ }^{25,26,42,54,57,59}$ all finding no association.

\section{Conclusion}

None of the previously investigated associations between occupation and prostate cancer risk could be confirmed with confidence in this prospective study. The lack of statistical significance for rubber workers could be caused by the scarcity of rubber workers in this cohort and subsequent lack of power. The results for policemen were statistically significant, despite our conservative 
false-positive rate. The reported increased prostate cancer risk of policemen is substantial and consistent within different time windows, different analyses, and consistent with other studies. At present, it is unclear what carcinogen could be responsible for this increased risk. Further research in this area is warranted.

\section{Acknowledgments}

The authors thank the participants of this study and further want to thank the regional cancer registries (IKA, IKL, IKMN, IKN, IKO, IKR, IKST, IKW, IKZ) and the Dutch National Database of Pathology (PALGA); Drs. A. Kester for statistical advice; S. van de Crommert, T. van Moergastel, J. Nelissen, C. de Zwart, M. Moll, W. van Dijk, P. Florax, and A. Pisters for assistance; and $\mathrm{H}$. van Montfort, R. Schmeitz, T. van Montfort, and M. de Leeuw for programming and statistical assistance.

The Dutch Cancer Society supported the Netherlands Cohort Study.

\section{References}

1. Hsing AW, Tsao L, Devesa SS. International trends and patterns of prostate cancer incidence and mortality. Int $J$ Cancer. 2000;85:60-67.

2. Schuurman AG, Goldbohm RA, Dorant E, et al. Vegetable and fruit consumption and prostate cancer risk: a cohort study in The Netherlands. Cancer Epidemiol Biomarkers Prev. 1998;7:673-680.

3. Schuurman AG, Goldbohm RA, van den Brandt PA. A prospective cohort study on consumption of alcoholic beverages in relation to prostate cancer incidence (The Netherlands). Cancer Causes Control. 1999;10:597-605.

4. Schuurman AG, van den Brandt PA, Dorant E, et al. Animal products, calcium and protein and prostate cancer risk in The Netherlands Cohort Study. Br J Cancer. 1999;80:1107-1113.

5. Schuurman AG, Zeegers MP, Goldbohm RA, et al. A case-cohort study on prostate cancer risk in relation to family history of prostate cancer. Epidemiology. 1999;10: 192-195.

6. Schuurman AG, Goldbohm RA, Dorant E, et al. Anthropometry in relation to prostate cancer risk in The Netherlands Cohort Study. Am J Epidemiol. 2000; 151:541-549.

7. Vlajinac HD, Marinkovic JM, Ilic MD, et al. Diet and prostate cancer: a casecontrol study. Eur J Cancer. 1997;33: 101-107.

8. Giles G, Ireland P. Diet, nutrition and prostate cancer. Int J Cancer. 1997;Suppl 10:13-17.

9. Hiatt RA, Armstrong MA, Klatsky AL, et al. Alcohol consumption, smoking, and other risk factors and prostate cancer in a large health plan cohort in California (United States). Cancer Causes Control. 1994;5:66-72.

10. Hsing AW, McLaughlin JK, Zheng W, et al. Occupation, physical activity, and risk of prostate cancer in Shanghai, People's Republic of China. Cancer Causes Control. 1994;5:136-140.

11. Brownson RC, Chang JC, Davis JR, et al. Physical activity on the job and cancer in Missouri. Am J Public Health. 1991;81: 639-642.

12. $\mathrm{Yu} \mathrm{H}$, Harris RE, Wynder EL. Casecontrol study of prostate cancer and socioeconomic factors. Prostate. 1988;13: 317-325.

13. Nomura AM, Kolonel LN. Prostate cancer: a current perspective. Epidemiol Rev. 1991;13:200-227.

14. Norman A, Moradi T, Gridley G, et al. Occupational physical activity and risk for prostate cancer in a nationwide cohort study in Sweden. Br J Cancer. 2002;86: 70-75.

15. Pienta KJ, Esper PS. Risk factors for prostate cancer. Ann Intern Med. 1993; 118:793-803.

16. Acquavella J, Olsen G, Cole P, et al. Cancer among farmers: a meta-analysis. Ann Epidemiol. 1998;8:64-74.

17. Blair A, Malker H, Cantor KP, et al. Cancer among farmers. A review. Scand J Work Environ Health. 1985;11:397407.

18. Blair A, Zahm SH, Pearce NE, et al. Clues to cancer etiology from studies of farmers. Scand J Work Environ Health. 1992;18:209-215.

19. Keller Byrne JE, Khuder SA, Schaub EA. Meta-analyses of prostate cancer and farming. Am J Ind Med. 1997;31:580586.

20. Kogevinas M, Sala M, Boffetta P, et al. Cancer risk in the rubber industry: a review of the recent epidemiological evidence. Occup Environ Med. 1998;55:112.

21. Van Der Gulden JW, Vogelzang PF. Farmers at risk for prostate cancer. $\mathrm{Br} J$ Urol. 1996;77:6-14.

22. van der Gulden JW. Metal workers and repairmen at risk for prostate cancer: a review. Prostate. 1997;30:107-116.

23. Parent ME, Siemiatycki J. Occupation and prostate cancer. Epidemiol Rev. 2001;23:138-143.

24. Blair A, Walrath J, Rogot E. Mortality patterns among US veterans by occupa- tion. I. Cancer. J Natl Cancer Inst. 1985; 75:1039-1047.

25. van der Gulden JW, Kolk JJ, Verbeek AL. Work environment and prostate cancer risk. Prostate. 1995;27:250-257.

26. Krstev S, Baris D, Stewart PA, et al. Risk for prostate cancer by occupation and industry: a 24-state death certificate study. Am J Ind Med. 1998;34:413-420.

27. van den Brandt PA, Goldbohm RA, van het Veer $\mathrm{P}$, et al. A large-scale prospective cohort study on diet and cancer in The Netherlands. J Clin Epidemiol. 19; 43:285-295.

28. Prentice RL. A case-cohort design for epidemiologic cohort studies and disease prevention trials. Biometrika. 19;73:111.

29. van den Brandt PA, Schouten LJ, Goldbohm RA, et al. Development of a record linkage protocol for use in the Dutch cancer registry for epidemiological research. Int J Epidemiol. 19;19:553-558.

30. Goldbohm RA, van den Brandt PA, Dorant E. Estimation of the coverage of Dutch municipalities by cancer registries and PALGA based on hospital discharge data. Tijdschr Soc Gezond. 19;72:80-84.

31. Centraal Bureau voor de Statistiek. Beroepenclassificatie 1984: lijst van benamingen per beroepencode. Voorburg: CBS; 1985.

32. Volovics A, van den Brandt PA. Methods for the analyses of case-cohort studies. Biometrical Journal. 1997;2:195-214.

33. Stata Statistical Software: Release 7.0 [program]. College Station, TX: Stata Corp; 2000.

34. Barlow WE. Robust variance estimation for the case-cohort design. Biometrics. 1994;50:1064-1072.

35. Lin DY, Ying Z. Cox regression with incomplete covariate measurements. JASA. 19;88:1341-1349.

36. Aickin M, Gensler H. Adjusting for multiple testing when reporting research results: the Bonferroni vs Holm methods. Am J Public Health. 1996;86:726-728.

37. Van der Vaart W. Inquiring Into the Past: Data Quality of Responses to Retrospective Questions. Vrije Universiteit; 1996.

38. Aronson KJ, Siemiatycki J, Dewar R, et al. Occupational risk factors for prostate cancer: results from a case-control study in Montreal, Quebec, Canada. Am J Epidemiol. 1996;143:363-373.

39. Krstev S, Baris D, Stewart P, et al. Occupational risk factors and prostate cancer in US blacks and whites. Am J Ind Med. 1998;34:421-430.

40. Howe GR, Fraser D, Lindsay J, et al. Cancer mortality (1965-77) in relation to diesel fume and coal exposure in a cohort 
of retired railway workers. J Natl Cancer Inst. 1983;70:1015-1019.

41. Sharma Wagner S, Chokkalingam AP, Malker HS, et al. Occupation and prostate cancer risk in Sweden. J Occup Environ Med. 2000;42:517-525.

42. Elghany NA, Schumacher MC, Slattery ML, et al. Occupation, cadmium exposure, and prostate cancer. Epidemiology. 1990;1:107-115.

43. Andersen A, Barlow L, Engeland A, et al. Work-related cancer in the Nordic countries. Scand J Work Environ Health. 1999;25(suppl 2):1-116.

44. Finkelstein MM. Cancer incidence among Ontario police officers. Am J Ind Med. 1998;34:157-162.

45. Forastiere F, Perucci CA, Di Pietro A, et al. Mortality among urban policemen in Rome. Am J Ind Med. 1994;26:785-798.

46. Checkoway H, DiFerdinando G, Hulka BS, et al. Medical, life-style, and occupational risk factors for prostate cancer. Prostate. 1987;10:79-88.

47. Fincham SM, Hanson J, Berkel J. Patterns and risks of cancer in farmers in Alberta. Cancer. 1992;69:1276-1285.
48. Simonato L, Fletcher AC, Andersen A, et al. A historical prospective study of European stainless steel, mild steel, and shipyard welders. Br J Ind Med. 1991;48: 145-154.

49. Miller BA, Blair A, Reed EJ. Extended mortality follow-up among men and women in a US furniture workers union. Am J Ind Med. 1994;25:537-549.

50. Hoar SK, Blair A. Death certificate casecontrol study of cancers of the prostate and colon and employment in the textile industry. Arch Environ Health. 1984;39: 280-283.

51. Stellman SD, Demers PA, Colin D, et al. Cancer mortality and wood dust exposure among participants in the American Cancer Society Cancer Prevention Study-II (CPS-II). Am J Ind Med. 1998;34:229237.

52. Matanoski GM, Stockwell HG, Diamond EL, et al. A cohort mortality study of painters and allied tradesmen. Scand $J$ Work Environ Health. 1986;12:16-21.

53. Guberan E, Usel M, Raymond L, et al. Disability, mortality, and incidence of cancer among Geneva painters and elec- tricians: a historical prospective study. Br J Ind Med. 1989;46:16-23.

54. Le Marchand L, Kolonel LN, Yoshizawa $\mathrm{CN}$. Lifetime occupational physical activity and prostate cancer risk. Am J Epidemiol. 1991;133:103-111.

55. Reif JS, Pearce NE, Fraser J. Cancer risks among New Zealand meat workers. Scand J Work Environ Health. 1989;15: 24-29.

56. Coggon D, Wield G. Mortality of butchers and cooks identified from the 1961 census of England and Wales. Oсcup Environ Med. 1995;52:157-159.

57. Buxton JA, Gallagher RP, Le ND, et al. Occupational risk factors for prostate cancer mortality in British Columbia, Canada. Am J Ind Med. 1999;35:82-86.

58. Oishi K, Okada K, Yoshida O, et al. Case-control study of prostatic cancer in Kyoto, Japan: demographic and some lifestyle risk factors. Prostate. 1989;14: 117-122.

59. van der Gulden JW, Kolk JJ, Verbeek AL. Prostate cancer and work environment. J Occup Med. 1992;34:402-409. 